Graddol, D. (2006). English Next The British Council Publications. London, UK.

ICAEA, (2021). ICAO LPR Test Design Guidelines \& Workshops. URL: https://www.icaea.aero/projects/icao-lpr-tdg/

ICAEA. (2019). TDG WORKSHOPS 2019: Using the ICAO LPR Test Design Guidelines». URL: https://www.icaea.aero/projects/icao-lpr-tdg/workshops/

УДК 37.015.3:[003.63:364-787.26]:[373:378]

DOI: https://doi.org/10.35387/od.2(20).2021.125-133

\begin{tabular}{|c|c|}
\hline $\begin{array}{lrr}\text { Рибалка } & \text { Валентин } \\
\text { Васильович } & - & \text { доктор } \\
\text { психологічних наук, } & \text { профресор, } \\
\text { провідний науковий співробітник }\end{array}$ & $\begin{array}{lll}\text { Rybalka Valentyn } & - \text { Doctor } \\
\text { of Sciences in } & \text { Psychology, } \\
\text { Professor, Leading } & \text { Researcher } \\
\text { of the Labour } & \text { Psychology }\end{array}$ \\
\hline 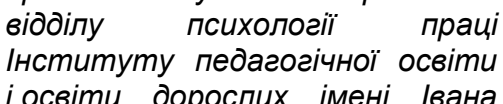 & $\begin{array}{l}\text { Department of the Ivan Zi } \\
\text { Institute of Pedagogical and } \\
\text { Education of the NAFS of Ukr: }\end{array}$ \\
\hline
\end{tabular}

Зязюна НАПН України

ORCID iD: https://orcid.org/0000-0002-8279-7468

E-mail: valentyn.rybalka@gmail.com

\title{
ПСИХОПЕДАГОГІКА ПРОЄКТНОЇ ДІЯЛЬНОСТІ ОСЕРЕДКУ ТЕРИТОРІАЛЬНОЇ ГРОМАДИ В УМОВАХ ДЕЦЕНТРАЛІЗАЦІЇ
}

\begin{abstract}
Анотація. У статті проаналізовано досвід організації проєктної діяльності освітянського осередку територіальної громади як форми ії демократичної поведінки в умовах рефоорми децентралізації влади. На основі узагальнення поглядів американського фрілософа і педагога Д. Д'юї, педагогічної системи А.С. Макаренка, досвіду відповідної роботи громадянського суспільства Швейцарії, США та офріційних документів, зокрема Конституції України (1996), Указу Президента України «Про сприяння розвитку громадянського суспільства в Україні» від 26 лютого 2016 року (2016), Концепції розвитку громадянської освіти в Україні (2018) тощо, запропоновано проєктно орієнтований алгоритм роботи освітянського осередку громадянського суспільства в умовах закладів освіти як центрів територіальних громад. Даний алгоритм був апробований в ході психологопедагогічних експедицій в ряді областей України у формі проведення тренінгу. Він передбачає 5 етапів, що відповідають принципам і процедурам демократії, засадам формування осередку громадянського суспільства, організації його продуктивної роботи, зокрема: 1. Збір членів громади, ї самоорганізація та правова підготовка. 2. Висування нагальних ініціатив, проблем, обговорення пропозицій та їх пріорітетивізація шляхом голосування. 3. Формування осередком проєктів вирішення пріоритетних проблем та їх прийняття референдумом. 4.Мобілізація суспільних, державних, кадрових, фрінансових ресурсів на виконання прийнятих проєктів. 5. Втілення проєктів у життя.

Вказаний алгоритм, тренінг і побудована на його основі технологія роботи реалізуються через послідовність дій освітянського осередку громадянського суспільства, що відповідають специсріці та графріку роботи
\end{abstract}


територіальної громади і осередку громадянського суспільства. Структура проєкту включає такі його складові, як: аналіз проголосованої пріоритетної проблема; прийняття назви проєкту; постановка мети; визначення методів, виконавців, ресурсів, термінів виконання; контроль та відповідальність за виконання; прогнозування очікуваного ефекту; організація співпраці громадянського суспільства, влади і державних установ; технічне та економічне офрормлення прийнятого проєкту у план дій та його подальще інноваційне просування. Дана технологія потребує свого подальшого удосконалення у певних напрямках.

Ключові слова: реформа децентралізації влади; територіальна громада; демократизація освіти; психопедагогічні засади; освітянський осередок; проєктна діяльність; алгоритм і тренінг.

\title{
Rybalka Valentyn
}

\section{PSYCHOPEDAGOGY OF PROJECT ACTIVITY OF THE TERRITORIAL COMMUNITY UNIT IN CONDITIONS OF DECENTRALIZATION}

\begin{abstract}
The article analyzes the experience of organizing the project activities of the educational unit of the territorial community as a form of its democratic behavior in the context of decentralization reform. Based on the generalization of the views of the American philosopher and educator D. Dewey, the pedagogical system of $A$. Makarenko, the experience of the relevant work of civil society in Switzerland, USA and official documents, including the Constitution of Ukraine (1996) and the Concept of Development of Civic Education in Ukraine (2018), etc., a project-oriented algorithm of educational center of civil society work in terms of educational institutions as centers of territorial communities is presented. This algorithm was tested during psychological and pedagogical expeditions in a number of regions of Ukraine in the form of training. It provides 5 stages that correspond to the principles and procedures of democracy, the principles of forming a unit of civil society, the organization of its productive work, in particular: 1. Gatherings of community members, its self-organization and legal training. 2. Nomination of urgent initiatives, problems, discussion of proposals and their priority by voting. 3. Formation of projects of the decision of priority problems by the unit, and their acceptance by referendum. 4. Mobilization of public, state, personnel, financial resources for the implementation of accepted projects. 5. Implementation of projects.
\end{abstract}

This algorithm, training and technology based on it are implemented through a sequence of actions of the educational unit of civil society, corresponding to the specifics and schedule of the territorial community and the unit of civil society. The structure of the project includes such components as: analysis of the voted priority problem; adoption of the project name; goal setting; definition of methods, implementors, resources, terms of implementation; control and responsibility for implementation; forecasting the expected effect; organization of cooperation between civil society, government and state agencies; technical and economic design of the adopted project in the action plan and its further innovative promotion. This technology needs further improvement in certain areas.

Key words: reform of government decentralization; territorial community; democratization of education; psychopedagogical principles; educational unit; project 
activity; algorithm and training.

Постановка проблеми та її актуальність. В процесі реформи децентралізації влади та створення територіальних громад і центрів по всій Україні постає як стратегічна проблема побудови громадянського суспільства як інституту прямої демократії і підготовка громадян до цієї роботи. На вирішення цієї проблеми спрямована Концепція розвитку громадянської освіти в Україні (2018), в якій враховані відповідні положення Закону України «Про освіту» та Концепції реалізації державної політики у сфері реформування загальної середньої освіти «Нова українська школа».

При цьому слід враховувати ту обставину, що ще на початку XX ст. американський філософ і педагог Джон Д'юї показав, що одним із найважливіших проявів демократичної діяльності громади є проєкт, який створюється нею на шляху покращення життя суспільства і країни (Д'юї, 2003). Саме тому цей спеціаліст був запрошений 1928 року тодішнім керівництвом країни в якості радника Наркомпросу з питань запровадження методу проєкту у систему освіти. Одним з тих, хто відгукнувся на цю ініціативу, став А.С. Макаренко, який поклав в основу своєї всесвітньо відомої педагогічної системи проєкт виховання культурного працівника, а в поточній роботі своєї колонії та комуни використовував цей метод як головний у роботі учнівського колективу (Рибалка, 2019).

Аналіз актуальних досліджень і публікацій. В Україні існують відомі історичні приклади функціонування прототипів громадянського суспільства, що виявлялися раніше у різних формах - від народного віча, козацьких рад, сільських і міських громад до майданів і сучасних територіальних громад тощо. Рух до демократичного громадянського суспільства України пов'язаний з діяннями її духовної еліти, зокрема таких мислителів, як Г. С. Сковорода, Т.Г. Шевченко, М.П. Драгоманов, Л. Українка, І.Я. Франко, В.І.Вернадський, Г.Г. Ващенко, А.С. Макаренко, В.О. Сухомлинський, О.Т. Гончар, О. А. Захаренко, Ф.Т. Моргун, І.А. Зязюн, а також В.П. Андрущенко, Н.Г. Джинчарадзе, М.А. Ожеван, А.В. Толстоухов, А.Ф. Ткачук та ін.

Мета статті полягає у визначенні сучасних засобів організації проєктної діяльності територіальної громади як фрорми становлення громадянського суспільства на базі закладів освіти в умовах реформи децентралізації влади.

Розвиток громадянського суспільства в Україні відбуватиметься ефективніше, якщо до цього процесу залучиться система освіти, коли школа або інший заклад освіти виступатиме центром інтеграції територіальної громади, що створюється в межах міського масиву, селища міського типу або об'єднання сіл. Ця ідея активно обговорюється й втілюється фрахівцями як перспективний варіант вирішення даної проблеми.

Виклад основного матеріалу дослідження. В умовах реформи децентралізації влади школа дійсно виступає в територіальній громаді в якості природного центру фрормування i функціонування осередку 
громадянського суспільства, особливо у сільській місцевості. Цьому сприяє зосередження в ній значного культурного, виховного, кадрового, організаційного та громадянського потенціалу, на основі чого такий осередок може ефективно виконувати функції демократизації усього суспільства. Слід враховувати також наявність в школі практичного психолога, соціального педагога, викладачів гуманітарних дисциплін української мови та літератури, історії, основ громадянського виховання тощо. До того ж заклади освіти концентрують в собі громадянський потенціал старшокласників і студентів, які вже мають паспорти громадян України, викладачів і батьків як членів територіальної громади. Саме в закладах освіти під час виборів зазвичай працюють виборчі дільниці, завдяки чому вони стають причетними до виборів як важливої процедури демократії. Директори закладів освіти часто обираються депутатами місцевих рад, що ставить їх фактично в центр територіальної громади і робить джерелом демократичного розвитку держави і суспільства.

Узагальнюючи дані щодо діяльності громадянського суспільства у демократично розвинутих країнах світу, зокрема у Швейцарії, США та ін., враховуючи власний досвід роботи у цьому напрямку, нами була розроблена загальна схема роботи освітянського осередку територіальної громади і сорормований проєктно орієнтований алгоритм проведення зборів громадянського суспільства (Рибалка, 2019). Він включає наступні етапи роботи.

1. Збір членів громади, самоорганізація та правова підготовка осередку громадянського суспільства.

2. Висування членами осередку громадянського суспільства нагальних ініціатив, проблем, обговорення пропозицій, ресурсів щодо їх розв'язання та затвердження їх пріоритетності шляхом голосування.

3. Формування осередком громадянського суспільства проєктів вирішення пріоритетних проблем та їх прийняття референдумом як необхідних та обов'язкових для виконання.

4. Мобілізація суспільних, державних, кадрових, фрінансових ресурсів на виконання прийнятих проєктів, контроль та відповідальність виконавців.

5. Втілення результатів виконання проєктів у життя, забезпечення досконалості, наступності та неперервності роботи осередку громадянського суспільства.

Вказаний алгоритм і побудована на його основі технологія роботи реалізуються через послідовність дій осередку громадянського суспільства, що відповідає специфіці та графіку роботи територіальної громади і осередку громадянського суспільства. В такому разі алгоритм може бути розподіленим у часі і здійснюватися впродовж тижнів, місяців і років. Разом з цим нами відпрацьовується також і згорнутий у часі, компактний варіант реалізації цього алгоритму у вигляді проведення спеціального тренінгу демократичної діяльності. Він був апробований в ході спеціальних психопедагогічних експедицій впродовж 2018 і 2019 років в низці закладів освіти Волинської, Полтавської та Дніпропетровської 
областей (Рибалка, Моргун, Самодрин, 2019). В ході експедицій такі тренінги поєднувалися з відповідними науково-методичними семінарами. Вказаний алгоритм діяльності осередку громадянського суспільства поступово адаптувався до умов різних закладів освіти - загальноосвітніх шкіл, педагогічних коледжів, технікумів тощо.

Технологія створення і діяльності освітянського осередку громадянського суспільства має базуватися на розумінні сутності громадянського суспільства як інституту прямої демократії, визнанні і дотриманні принципів і процедур демократії та врахуванні особливостей формування територіальних громад в Україні (Рибалка, 2019; Ткачук, 2016). Про це слід особливо наголосити, оскільки в реальних територіальних громадах все ще спостерігається певний бюрократизм, «громадські» рішення приймаються одноосібно або вузькими колами деяких членів громади, вони затверджуються зборами формально, через що зникає сам творчий ефект прямої демократії, а демократичні процедури фрактично підмінюються авторитарними методами.

Громадянське суспільство $€$ відносно самостійним соціальним утворенням як за формою, так і за змістом виконуваних функцій. Це недержавна частина усього суспільства, яка базується на автономії індивідів (сім'я, школа, добровільні організації та союзи, духовним виразником інтересів яких $є$ суспільна думка). Громадянське суспільство поєднує економічні, соціальні, культурні, духовні, родинно-побутові відносини та інститути, а також передбачає певні свободи, права та обов'язки особистості як необхідні умови ії самоствердження та самореалізації у громадському житті (Джинчарадзе, Ожеван \& Толстоухов, 2006, с. 38).

Вищою цінністю громадянського суспільства визнаються особистість, її права та свободи. Розвиток громадянського суспільства зумовлює зростання самосвідомості особистості, розширення сфери ії соціально значимих ініціатив і водночас - гарантує ії вільну самореалізацію. До цінностей громадянського суспільства відносяться громадянські, політичні та соціально-політичні права. Це також цінності родини, суспільних та релігійних рухів, недержавних засобів масової інформації, органів громадського самоврядування, що утворюють механізм формування та вияву суспільної думки, розв'язання суспільних конфрліктів тощо. Права, свободи та обов'язки людини і громадянина представлені у розділі 2 Конституції України (1996).

Створення територіальних громад вважається першим i необхідним етапом реформи децентралізації влади, що активно здійснюється з 2014 року (Ткачук, 2016). В цих умовах, в центрі уваги постає так звана спроможна територіальна громада, створена на основі територіальних центрів у містах та громад у селах (селищах міського типу), що добровільно об'єднуються, здатна самостійно або через відповідні органи місцевого самоврядування забезпечити належний рівень надання послуг, зокрема у сфері освіти, культури, охорони здоров'я, соціального захисту та житлово-комунального господарства, з урахуванням кадрових ресурсів, фрінансового забезпечення та розвитку інфраструктури 
відповідної адміністративно-територіальної одиниці (Ткачук, 2016, с. 10-11).

Розглянемо технологію проведення проєктно орієнтованого тренінгу на прикладі роботи конкретного освітянському осередку, що складався з 25 директорів і заступників директорів загальноосвітніх шкіл м. Кременчука Полтавської області, що були запрошені на проведення відповідного тренінгу Управлянням освіти і науки міської державної адміністрації (тренінг проводився автором статті, якому асистував доктор педагогічних наук, професор Самодрин А.П.). Учасники тренінгу були об'єднані у 5 груп з обраними в кожній групі спікерами. Члени групи ініціативно і послідовно висували й обговорювали по дві проблеми, які фріксувалися у протоколі. Далі вони почергово презентувалися осередку спікерами груп і проголосовувалися щодо їх актуальності усіма учасниками осередку для визначення їх пріоритетності. Та проблема, яка набирала більшість голосів, ставала основою для розробки проєкту. Розроблений проєкт ставився на референдум осередку і після набору більшості голосів розглядався як обов'язковий для виконання відповідними державними установами та громадянським суспільством територіальної громади. В тому випадку, якщо цей проєкт не набирав в ході референдуму більшості голосів і відхилявся, то проводився повторний розгляд проголосованих раніше проблем і розроблявся наступний проєкт по проблемі, що набрала найбільше голосів.

Так, у нашому випадку основою проєкту стала запропонована одним 3 директорів (А.) «Проблема дефіциту і відродження духовної культури української родини». У ході осередкового референдуму він набрав +24 голоси, тобто майже всіх членів осередку. Розглянемо стисло структуру проєкту, розробленого даним осередком на основі вказаної пріоритетної проблеми.

Назва проєкту: «Програма відродження духовної культури української сім'ї як основи нації».

Meта: Втілення у заклади освіти гуманістичних цінностей засобами демократії і освіти.

Методи: Дослідження, опитування, пропаганда і просвіта, виховна система школи як осередку громадянського суспільства, процедури демократії.

Виконавці: Освітянське громадянське суспільство як організатор та колективний виконавець. Запропоновано передати проєкт в управління освіти і науки міської держадміністрації.

Ресурси: Достатнє державне забезпечення - фрінансове, кадрове, організаційне. Передбачається використання фонду фрінансування територіальної громади.

Термін: 5-6 років (термін президентської каденції нинішнього та початок каденції наступного президента).

Контроль і відповідальність: Громадянське суспільство як зразок і створена ним контрольна комісія з числа чесних членів і службовців.

Очікуваний ефект: формування більш гармонійних й ефективних демократичних стосунків між громадянами держави.

Після завершення тренінгу члени осередку обговорюють питання 
технічного та економічного оформлення прийнятого проєкту та його подальшого інноваційного просування. В даному випадку проєкт був переданий в Кременчуцьке міське управління освіти і науки, яке запланувало включити його у план роботи методологічного семінару керівників загальноосвітніх закладів освіти. В інших випадках (а всього у 2018-2019 рр. в ході психопедагогічних експедицій у закладах освіти трьох областей України було проведено 8 тренінгів і розроблено 6 проєктів) до доробки i конкретизації проєктів запрошуються юристи, економісти, представники влади, керівники місцевих підприємств, які разом з членами осередку доводять робочий варіант проєкту осередку громадянського суспільства до відповідності формальним вимогам, визначають порядок його виконання, кошторис, графік громадянського контролю та супроводу й інстанції технологічного проходження проєкту.

Проєкт має бути затверджений і профрінансований за рекомендацією територіальної громади районною або обласною радою і просунуто на більш високий загальнодержавний рівень виконання. Але він має залишитися і на рівні територіальної громади, тобто втілюватися, реалізуватися на місцевому рівні. Водночас виконавцями можуть стати волонтери з числа учнів, педагогів закладів освіти, батьків, мешканців територіальної громади.

Таким чином, описана вище технологія здійснення демократичної роботи освітянського осередку громадянського суспільства в закладі освіти як його інтегративного центру дозволяє виявляти прихований творчий потенціал громади. Старшокласникам, студентам, спеціалістам різних професій і громадянам, які хочуть самостійно опанувати основи демократичної поведінки в умовах громадянського суспільства, слід засвоїти різноманітні демократичні методи роботи, зокрема такі, як проведення зборів, дискусії та дебати, мозкова атака, алгоритм роботи осередків громадянського суспільства за швейцарською моделлю, американська технологія деліберації, техніка голосування та референдуму, проєктування, прийоми контролю та шляхи накладання відповідальності за виконання прийнятих рішень. Вони мають оволодіти демократією як певною філософією суспільного життя, наукою, мистецтвом, світоглядом тощо.

Висновки і перспективи подальших досліджень. Отже, узагальнюючи наявні дані з позицій сучасної психології та педагогіки, автор, спираючись також на власний досвід участі у громадянських подіях останніх років, у психологічних експедиціях, семінарах і тренінгах у навчальних закладах як центрів об'єднаних територіальних громад, пропонує певне бачення проблеми демократизації i створення громадянського суспільства в Україні, що виявилося, зокрема в розробці проєктно орієнтованої технології розвитку і функціонування його освітянського осередку. Ця технологія конкретизується, концентрується, зокрема в алгоритмі його роботи, у сценарії тренінгу побудови і функціонування такого осередку на демократичних засадах. Звичайно, що всі представлені у роботі пропозиції потребують додаткового обговорення, експертизи компетентними читачами, доповнення та удосконалення. $B$ 
перспективі передбачається доопрацювання запропонованої технології проєктної діяльності територіальних громад з урахуванням умов пандемії COVID-19, карантину та запровадження дистанційних фрорм роботи.

\section{Список використаних джерел}

Джинчарадзе, Н. Г. \& Ожеван, М. А. \& Толстоухов, А. В. та ін. (2006). Основи громадянського суспільства: Словник: Для студ. вищ. навч. закл. Київ: Знання України. 232.

Д'юї, Дж. (2003).Демократія і освіта. Львів: Літопис. 294.

Конституція України: Прийнята на п'ятій сесії Верховної Ради України 28 червня 1996.(1996). Київ: Феміна. 64.

Концепція розвитку громадянської освіти в Україні. (2018). Схвалено розпорядженням Кабінету Міністрів України від 3 жовтня 2018 року № 710-р. Ред. від 26.02.2020. Підстава: 76-2020p.https:/zakon.rada.gov.ua/laws/show/710-2018-p\#Text.

Рибалка, В.В.(2019). Самонавчання демократії юної та дорослої особистості: Методичний посібник. Київ: Талком. 208.

Рибалка, В. В. \& Самодрин, А. П. \& Моргун, В. Ф. (2019). Психопедагогічні експедиції шляхами демократизації життя особистості, освіти та громадянського суспільства: Методичний посібник. Київ: Талком. 280.

Ткачук, А. Ф. (2016). Децентралізація для всіх: від загальної інфоормації до конкретних порад. Київ: ІКЦ «Легальний статус». 52.

Указ Президента України №68/2016: «Про сприяння розвитку громадянського суспільства в Україні» від 26 лютого 2016 року. «Стратегія сприяння розвитку громадянського суспільства в Україні». (2016). Офріційне інтернет-представництво Президента України. httpllwww.president.gov.ua/documents/ 682016-19805.

\section{References (translated and transliterated)}

Dzhyncharadze, N. H., Ozhevan, M. A. \& Tolstoukhov, A. V. ta in. (2006). Osnovy hromadianskoho suspilstva: Slovnyk: Dlia stud. vyshch. navch. zakl. [Fundamentals of Civil Society: Dictionary: For students of higher textbook lock]. Kyiv: Znannia Ukrainy. 232 [in Ukrainian].

Diui, Dzh. (2003). Demokratiia i osvita [Democracy and education]. Lviv: Litopys. 294 [in Ukrainian].

Konstytutsiia Ukrainy: Pryiniata na piatii sesii Verkhovnoi Rady Ukrainy 28 chervnia 1996. (1996) [The Constitution of Ukraine: Adopted at the fifth session of the Verkhovna Rada of Ukraine on June 28, 1996]. Kyiv: Femina. 64 [in Ukrainian].

Kontseptsiia rozvytku hromadianskoi osvity $v$ Ukraini. Skhvaleno rozporiadzhenniam Kabinetu Ministriv Ukrainy vid 3 zhovtnia 2018 roku № 710-r. Red. vid 26.02.2020. (2018) [The concept of development of civic education in Ukraine. (2018). Approved by the order of the Cabinet of Ministers of Ukraine dated October 3, 2018 № 710-r. Ed. from 26.02.2020]. Pidstava: 176-2020-r. URL: https:/zakon.rada.gov.ua/laws/show/710-2018-p\#Text. [in Ukrainian].

Rybalka, V. V. (2019). Samonavchannia demokratii yunoi ta dorosloi osobystosti: Metodychnyi posibnyk [Self-study of democracy of young and adult 
personality: Methodical manual]. Kyiv: Talkom. 208 [in Ukrainian].

Rybalka, V. V., Samodryn, A. P. \& Morhun, V. F. (2019). Psykhopedahohichni ekspedytsii shliakhamy demokratyzatsii zhyttia osobystosti, osvity ta hromadianskoho suspilstva: Metodychnyi posibnyk [Psychopedagogical expeditions to democratize the life of the individual, education and civil society: A guide]. Kyiv: Talkom. 280 [in Ukrainian].

Tkachuk, A. F. (2016). Detsentralizatsiia dlia vsikh: vid zahalnoi informatsii do konkretnykh porad [Decentralization for all: from general information to specific advice]. Kyiv: IKTs «Lehalnyi status». 52 [in Ukrainian].

Ukaz Prezydenta Ukrainy №68/2016: «Pro spryiannia rozvytku hromadianskoho suspilstva v Ukraini» vid 26 liutoho 2016 roku. "Stratehiia spryiannia rozvytku hromadianskoho suspilstva v Ukraini». (2016) [Decree of the President of Ukraine №68 / 2016: «On promoting the development of civil society in Ukraine» of February 26, 2016. "Strategy for Promoting the Development of Civil Society in Ukraine»]. Ofitsiine internetpredstavnytstvo Prezydenta Ukrainy. URL: http|lwww.president.gov.ua/documents/ 682016-19805 [in Ukrainian].

Удк [37.013.83:005.336.2]:37.091.12:37.018.46

DOI: https://doi.org/10.35387/od.2(20).2021.133-144

Самко Алла Миколаївна кандидат педагогічних наук, старший науковий співробітник відділу андрагогіки Інституту педагогічної освіти $і$ освіти дорослих імені Івана Зязюна НАПН України
Samko Alla - Candidate of Pedagogical Sciences, Senior Researcher of the Andragogy Department of the Ivan Zyazyun Institute of Pedagogical and Adult Education NAES of Ukraine

ORCID iD: $h$ ttps://orcid.org/0000-0003-0785-0510

E-mail:alla-samko@ukr.net

\title{
ОСОБЛИВОСТІ АНДРАГОГІЧНОЇ КОМПЕТЕНТНОСТІ ПЕДАГОГІЧНОГО ПЕРСОНАЛУ ЗАКЛАДІВ ПІСЛЯДИПЛОМНОЇ ПЕДАГОГІЧНОЇ ОСВІТИ
}

\begin{abstract}
Анотація. В оглядовій статmі проаналізовано особливості профресійної діяльності андрагога в умовах безперервної освіти, охарактеризовано андрагогічну компетентність педагогічного персоналу закладів післядипломної педагогічної освіти. Зазначено, що андрагог, який працює з дорослими, повинен розуміти специфрічні цілі, що стоять перед різними категоріями дорослих-учнів, мотиви їх освітньої діяльності, вміти надавати освітню допомогу та забезпечувати соціально-психологічну підтримку, розвивати рефрлексивні вміння дорослих, вміти діагностувати освітні потреби та можливості дорослих.

На основі аналізу наукових джерел автором виокремлено особливості, що визначають специфріку андрагогічної компетентності
\end{abstract}

